\title{
MERCÚRIO ENTREVADO: MEMÓRIAS PÓSTUMAS DE BRÁS CUBAS EM TRAVESSIA
}

\section{DIANA DUARTE FERREIRA}

Universidade Nova de Lisboa

Lisboa, Portugal

Resumo: Inspirando-se na forma livre de Brás Cubas, o ensaio propõe uma releitura das Memórias Póstumas a partir de questões estruturantes como contingência e necessidade, fato e metáfora, obra e autor, vida e morte.

Palavras-chave: Memórias póstumas de Brás Cubas; "Teoria das edições humanas"; Morte; Errata; Delírio.

\section{MERCURY CONFINED: CROSSING THE POSTHUMOUS MEMOIRS OF BRÁS CUBAS}

Abstract: Inspired by Brás Cubas' free form, the essay puts forth a rereading of The Posthumous Memoirs based on structural issues like contingency and necessity, fact and metaphor, work and author, life and death.

Keywords: The Posthumous Memoirs of Brás Cubas; "Theory of human editions"; Death; Errata; Delirium.

\section{Prólogo profilático}

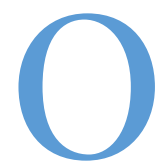

presente ensaio enquadra-se num contexto pandêmico. O exercício ajusta-se bem ao regime de trabalho remoto exigido pelo confinamento profilático, imposto àqueles cuja atividade não é considerada essencial. Se o mundo não tivesse parado, gentil legente, não estarias a ler este ensaio sobre as Memórias póstumas de Brás Cubas.

A pandemia - sim, o ensaio é sobre as Memórias, mas o livro é diverso e nem a epidemia deixa de parte - deve-se a um novo tipo de vírus, altamente eficaz no contágio, disseminado pelo globo em pouco tempo graças à 
mobilidade dos hospedeiros. Um dos sintomas mais típicos é a pneumonia, que pode provocar insuficiência respiratória e conduzir à morte. Brás Cubas morreu de pneumonia graças a uma "ideia fixa” (ASSIS, 2013, p. 26). A humanidade, com as suas fixas ideias, não ligou para o "golpe de ar" (ASSIS, 2013, p. 28) acompanhado de sintomas; pelo contrário, tentou abafá-los. Entretanto, era demasiado tarde. Agora assiste ao próprio declínio e delira pela edição seguinte. Refiro-me, como sabes, a uma teoria do autor. Também eu pretendo imitá-lo: focar-me no estilo e deixar a parte da pneumonia para a humanidade. Como podes ver, escrever é uma boa maneira de nos mantermos vivos.

Mas não te fies na minha imitação, a um passo falha e excessiva. $\mathrm{O}$ autor escreveu a difusa obra "com a pena da galhofa e a tinta da melancolia" e ainda assim conseguiu imprimir-lhe "algumas rabugens de pessimismo" (ASSIS, 2013, p. 17). Eu, com a mesma pena e a mesma tinta, só consigo pintar rabugens de otimismo.

\section{Não havia necessidade}

Criado e interpretado pelo humorista português Herman José, o personagem Diácono Remédios tinha uma atuação paralíptica: esmiuçava, hilariante, os assuntos cuja desnecessidade evocava. Há uma frase sua que permanece no imaginário português. Quando algo se revela adverso, é isso que se pensa e diz: "Não havia necessidade”. A pandemia não é exceção: havia necessidade, agora que a economia mundial tinha se recuperado? Havia necessidade de a referir num ensaio sobre as Memórias póstumas?

"Uns olhos tão lúcidos, uma boca tão fresca, uma compostura tão senhoril; e coxa! Esse contraste faria suspeitar que a natureza é às vezes um imenso escárnio. Por que bonita, se coxa? Por que coxa, se bonita?” (ASSIS, 2013, p. 103) O questionamento da necessidade é das grandes questões suscitadas pelo livro. Pôr em causa um evento ou uma contingência e duvidar da sua razão de ser é questionar a existência de uma inteligência superior (invariavelmente designada por "natureza" no romance) ou, pelo menos, de um destino determinista.

O autor fala de Eugénia sem rodeios. Além de lhe chamar "flor da moita” (ASSIS, 2013, p. 97) e "Vênus manca” (ASSIS, 2013, p. 103), refere: “[...] não sei é se a tua existência era muito necessária ao século. Quem sabe? Talvez um comparsa de menos fizesse patear a tragédia humana.” (ASSIS, 2013, p. 108). Nesta aceção, a tragédia humana implica uma autoria intencional que é alvo de crítica. 
Por outro lado - e esta reflexão já resulta de Eulália - Brás Cubas declara ter feito uma "descoberta subtil":

[...] a natureza previu a vestidura humana, condição necessária ao desenvolvimento da nossa espécie. A nudez habitual [...] tenderia a embotar os sentidos e retardar os sexos, ao passo que o vestuário, negaceando a natureza, aguça e atrai as vontades, ativa-as, reprodu-las, e conseguintemente faz andar a civilização. (ASSIS, 2013, p. 218)

Isto passa-se com o corpo, que interfere nas paixões da alma. Acrescento que se passa o mesmo com a alma, que interfere nas do corpo. Poderia a mente humana andar por aí despida de falsidade, omnisciente, transpirando pura gnose? Se assim fosse, que seria da curiosidade? Como poderia a gnose pura desconhecê-la? Poderíamos nós, que temos as consciências agasalhadas, conhecer algo ignorado por uma consciência que nunca tem frio? Talvez, caso não haja nenhuma pura gnose. Mas, se houver, dificilmente se poderá chamar-lhe humana, ao passo que ela não poderá saber o que é a curiosidade senão pelo indireto conhecimento do desconhecido. Será que é por isso que dizem que o ser humano foi feito à imagem e semelhança divina?

\section{Cruzamento de gênero}

Creio ter provado, no item anterior, que as Memórias póstumas são um romance filosófico. Não era a minha intenção; fica demonstrado que não é preciso muito para o revelar, e que há coisas que se provam sem querer.

Não estamos perante um "puro romance" ou um "romance usual" (ASSIS, 2013, p. 17), mas diante de um romance autobiográfico postumamente escrito. $\mathrm{O}$ autor sabe como termina a sua vida, o que em princípio não está ao alcance de um autobiógrafo. Outra coisa que pode não estar ao alcance desse último é certa faculdade, necessária aos romancistas, "partícula da sabedoria" com que o céu contempla Brás Cubas: “[...] o dom de achar as relações das cousas, a faculdade de as comparar e o talento de concluir!”. E acrescenta: “Eu tive essa distinção psíquica; eu a agradeço ainda agora do fundo do meu sepulcro.” (ASSIS, 2013, p. 266). Tem atenção a esta frase, pois regressará no final.

Pressupõem-se claras diferenças entre os dois gêneros. A linearidade inacabada da autobiografia rivaliza com a plasticidade teleológica do romance. A pressuposição da ficção, no romance, contrasta com a da verdade, na 
autobiografia. Mas os limites são incertos: não pode um romance conter factos disfarçados de ficções, e uma autobiografia, ficções disfarçadas de factos? Uma das vantagens dos defuntos relativamente aos vivos é o "desdém dos finados". A opinião, "[...] esse olhar agudo e judicial, perde a virtude, logo que pisamos o território da morte” (ASSIS, 2013, p. 84).

Brás Cubas a um passo relata e reinterpreta os factos da sua vida. A reordenação dos episódios vividos, ou melhor, a transformação dos episódios vividos em episódios narrados, resulta desse cruzamento e não teria lugar sem o conhecimento télico que é próprio do romance. Verificam-se, assim, dois planos cruzados: o autobiográfico, de índole factual; e o romanesco, de índole metafórica.

\section{Três partes}

Entre o relato da morte e o do nascimento, "a maior transição deste livro" (ASSIS, 2013, p. 41), Brás Cubas introduz-nos quatro aspetos fulcrais: a) a ideia fixa que toma a forma de "emplasto Brás Cubas" e o conduz à morte; b) a genealogia e história do apelido Cubas, introduzindo o pai como ficcionista e explicando a "paixão do arruído" do filho, confessada no capítulo prévio, como possível produto dessa ficção; c) Virgília, "imponente ruína” (ASSIS, 2013, p. 28), leva-o a mencionar, em paralipse, a "teoria das edições humanas" (ASSIS, 2013, p. 29); d) o delírio. É a esta secção que o próprio Brás Cubas chama "primeira parte do livro" (ASSIS, 2013, p. 314). Entre o nascimento e a morte, podemos situar o limite da segunda e terceira partes no momento de regresso ao Rio, precipitado pela morte iminente da mãe. O retorno de Brás Cubas à família será mote de uma série de regressos e restituições que definem a construção do romance até o fim.

\section{O Esfingimento}

O "Emplasto Brás Cubas" é descrito como "medicamento sublime" (ASSIS, 2013, p. 22). Com "duas faces” (ASSIS, 2013, p. 22), destinava-se a paliar não apenas a melancolia da humanidade, mas também a "flor amarela" de Brás (ASSIS, 2013, p. 85). O estado de hipocondria é atingido pela primeira vez depois da morte da mãe, que o faz regressar ao Brasil e isolar-se na Tijuca. A flor é complexa e biface: "solitária e mórbida", exala um cheiro "inebriante e sutil" (ASSIS, 2013, p. 85). A dor era "taciturna", mas apertá-la "ao peito" provocava "uma sensação única, uma cousa a que poderia chamar volúpia do aborrecimento", "uma das sensações mais subtis desse mundo e daquele 
tempo"... e Brás Cubas deixava-se "atoar de ideia em ideia [...] como uma borboleta vadia ou faminta" (ASSIS, 2013, p. 86).

Podemos inferir que se encontrava em semelhante estado de hipocondria imediatamente antes de ser assaltado pela ideia fixa do emplasto. A diferença é que a borboleta errante se constituiu trapézio fixo num eixo que o mobiliza à receção das ideias, as quais deixaram de ser pontos fixos selecionados pelo autor e passaram a ir ao seu encontro, de forma mais ou menos breve e intensa, enquanto figuras dinâmicas.

Uma vez pendurada, entrou a bracejar, a pernear, a fazer as mais arrojadas cabriolas de volatim, que é possível crer. Eu deixei-me estar a contemplá-la. Súbito, deu um grande salto, estendeu os braços e as pernas, até tomar a forma de um X: decifra-me ou devoro-te. (ASSIS, 2013, p. 22)

O defunto autor traduz o X com uma evocação enigmática da Esfinge. A metáfora não deve ser subestimada, porque nos informa sobre um arco de causalidade entre a vida e a morte do autor. Valorizar a metáfora é poder indagar pelo menos duas coisas a partir da morte, e a primeira é se este não terá decifrado erradamente o enigma. É provável que a sua natureza fosse antropocêntrica, cenário onde Brás representaria a célula impermanente e anônima de um organismo regulador e aglomerante. A decifração eleita é, porém, egocêntrica: o que "influiu principalmente" Brás Cubas "foi o gosto de ver impressas nos jornais, mostradores, folhetos, esquinas, e enfim nas caixinhas do remédio, estas três palavras: Emplasto Brás Cubas.” (ASSIS, 2013, p. 22). De facto, as caixinhas surgem em último lugar na enumeração, e o remédio em si não chega a ser inventado. O segundo aspeto a indagar é se uma das coisas que se alteram entre a vida e a morte de Brás não é precisamente a consciência do erro que lhe custou a vida e, quem sabe, a consciência daquela que poderia ter sido uma decifração mais adequada.

Também podemos indagar se o erro não resulta da distorção de um fundamento que até seria ajuizado no campo das ideias. Nomeadamente, o facto de as ideias fixas serem um excelente remédio para a melancolia ou trampolim para a atividade. Tal como todos os remédios, pode ter efeitos secundários e até conduzir à morte caso seja administrada em elevadas doses. Cubas adverte: "Deus te livre, leitor, de uma ideia fixa [...]" (ASSIS, 2013, p. 26). 


\section{0 tornado do Texas}

Só se vem a saber de que trata a "teoria das edições humanas" depois do regresso de Brás e após uma série de peripécias que ajudam a determinarlhe o destino, constituídas também por regressos e borboletas, que talvez fosse um título melhor para o item.

Motivo recorrente e alegórico, a borboleta leva-nos ao ensaio "A Vênus manca (emenda de Pascal)", de Abel Barros Baptista, e à teoria do caos de Edward Lorenz. Vamos ao último: matemático e meteorologista americano, comprovou com incredulidade que a mínima alteração numa variável podia provocar enormes e imprevisíveis perturbações no sistema. Em 1972, publicava a teoria com o seguinte título: "Predictability; Does the Flap of a Butterfly's wings in Brazil Set Off a Tornado in Texas?"

Eugénia, "flor da moita" (ASSIS, 2013, p. 97), é o "tornado do Texas", e Brás, a sua "borboleta preta" (ASSIS, 2013, p. 98-99). Conclusão invulgar, bem sei, mas remeto-a a um episódio decisivo da infância do autor. Quando a criança impaciente não se contém durante o banquete e é tirada da mesa sem chegar a comer o doce desejado, o culpado é o Dr. Vilaça que não parava de improvisar versos. O menino decide vingar-se, seguindo-o e a D. Eusébia, sorrateiramente, até à moita onde o casal pretendia abrigar-se de quaisquer olhares. Trocado um beijo, Brás Cubas gritou a todos o sucedido... eis o primeiro romance publicado!

A vingança, movida pelo protelar da sobremesa, trouxe óbvios dissabores, e trouxe-os sobretudo a quem não era o alvo a abater. Achas que exagero ao colocar a hipótese de o vexame ter impedido D. Eusébia de encontrar um homem com quem contraísse uma relação de legitimidade extensível aos filhos? Achas que a vingança não precipitou a condenação da pobre dama ao concubinato adulterino com o Dr. Vilaça, "casado e pai" (ASSIS, 2013, p. 51)? A partir do dia em que Brás não pôde provar a sobremesa, D. Eusébia não pôde provar senão o Dr. Vilaça: a filha e o "bom legado" (ASSIS, 2013, p. 86) que o glosador lhes deixa constituem provas sólidas disso mesmo. Eugénia é a “flor da moita”, isto é, do adultério, do impublicável etc. É também a flor do jardim público em que D. Eusébia foi depositada por Brás Cubas. O arco descrito pelo pequeno gesto de retribuição infantil culmina, muitos anos depois, na longa desgraça de Eugénia, reencontrada na miséria por Brás Cubas.

Estava ele na primeiríssima edição, pelo que dificilmente podia prever as consequências nefastas da vingança. Ainda assim, edições depois, já adulto e prestes a visitar D. Eusébia e a filha, Brás Cubas continuava a não levar em 
conta a influência exercida sobre aqueles destinos: “[...] senti-me vexado; mas adverti que os acontecimentos tinham-me dado razão. $\mathrm{Na}$ verdade, fora impossível evitar as relações íntimas do Vilaça com a irmã do sargento-mor” (ASSIS, 2013, p. 586. Eugénia representa o regresso de um passado que clama por revisão, uma consequência que clama por justiça. Talvez a única maneira de restituir a justiça fosse o casamento entre ela e Brás Cubas. Ironia do destino, caso este tivesse ignorado o "pouco, tão pouco" coxear de Eugénia (ASSIS, 2013, p. 101), o matrimônio poderia ter dado ao autor a paternidade tão desejada.

\section{A quarta edição}

Entretanto, Brás regressa à cidade e vai ao encontro de Virgília. A "imponente ruína" era então flor que desabrochava, concatenando o projeto duplo que o pai Cubas reservava ao filho: casamento e lugar de deputado. Tudo parecia encaminhado, estavam "íntimos" (ASSIS, 2013, p. 109); mas uma curiosa sucessão de eventos deita por terra o projeto do pai, em sentido figurado; e o próprio pai, literalmente.

Se estava, assim, esta "quarta edição, revista e emendada, mas ainda inçada de descuidos e barbarismos” (ASSIS, 2013, p. 110), que necessidade havia do regresso da primeira, sobretudo num dia em que tinha um compromisso sério com a "noiva" e seus pais? Refiro-me ao reencontro de Brás com Marcela, primeiro amor, bela mulher que vivia do poliamor. Brás começara a gastar com ela a herança muitos anos antes da morte do pai: “[...] entrei a sacar sobre a herança de meu pai, a assinar obrigações, que devia resgatar um dia com usura" (ASSIS, 2013, p. 59). Nos títulos de dívida circulava, implícita, a morte do progenitor. Quando descobriu, o pai Cubas resgatou as dívidas e o filho, enviando-o para Coimbra.

Não estava atrasado para o jantar em casa de Virgília, pelo contrário: foi "dar várias voltas" (ASSIS, 2013, p. 110). Estava adiantado, por isso fazia tempo. Não queria atrasar-se, por isso consultava o tempo feito. Na rua dos Ourives, cai-lhe o vidro do relógio. Entrando na primeira loja, depara-se com o "espetáculo curioso" de Marcela (ASSIS, 2013, p. 110). Os olhos da quarta edição veem-lhe a cobiça que os da primeira não viam, embora cobiçassem apenas a ela. O reencontro finalmente impele Brás Cubas a uma revisão do passado, a um reconhecimento num momento em que o futuro já tinha hora marcada. A cena arrasta-se e o noivo acaba por se atrasar além do admissível: “Esperávamos que viesse mais cedo.” (ASSIS, 2013, p. 117). 
“Temos que Marcela, recebendo um piparote do passado rolou até tocar em Brás Cubas - o qual, cedendo à força impulsiva, entrou a rolar também até esbarrar em Virgília, que não tinha nada com a primeira [...]” (ASSIS, 2013, p. 119). Será que não tinha? Afinal, a última fica retratada como aquela que cobiça em segredo codicilos dos moribundos. Virgília ficou de mau humor e deixou-se arrebatar, com o lugar de deputado, por outro candidato. Lobo Neves tomou-a "com um ímpeto verdadeiramente cesariano" (ASSIS, 2013, p. 120). Brás, que havia saído vencedor de uma rivalidade idêntica com Marcela, alcançando a "fase cesariana" (ASSIS, 2013, p. 58) do relacionamento, é obrigado a depor as insígnias na quarta edição. Custa-lhe uma noite em branco, não porque a amasse, mas devido a um "despeitozinho agudo como ponta de alfinete" (ASSIS, 2013, p. 121).

\section{De mãos dadas}

No capítulo I, Brás Cubas destaca as "duas considerações" que o levaram a principiar o romance pela morte. A segunda é a originalidade, mas agora ocupo-me da primeira: "eu não sou propriamente um autor defunto, mas um defunto autor”. Entendemos que só se tornou autor depois de morrer, e a esse ato inaugural dedico esta parte.

Por agora, parece-me pertinente analisar ambas as expressões com o vagar próprio da profilaxia. Achas que "defunto autor" descreve apenas a situação única de Brás Cubas? Por exemplo, achas que a expressão "póstuma obra” descreve apenas as Memórias póstumas? Não; pode referir-se a qualquer outra obra publicada depois da morte do autor. Para responder à primeira pergunta, observaremos o modo como Machado de Assis, simultaneamente autor e defunto, se encaixa nelas. Por um lado, é morto; por outro, está longe de ser esquecido, que é a segunda aceção de defunto.

Não é difícil conceber que haja autores vivos mais defuntos do que os finados, que aliás são a maioria. A fasquia da vida para além da morte é elevada. Ser autor exige uma obra, uma obra exige trabalho, o trabalho exige tempo, o tempo exige espaço e o espaço exige muito. Não é difícil conceber que grandes obras fiquem pelo caminho, borboletas esmagadas a meio do voo. Quincas Borba, autor do Humanitismo, foi tomado pela sandice; antes de morrer, queimou "o manuscrito todo e ia recomeçá-lo" (ASSIS, 2013, p. 312) ainda outra vez, a fim de o aperfeiçoar. Como questiona Baptista: “[...] a sorte da borboleta é determinada pela contingência das suas qualidades ou pela superioridade daquele com quem se encontra?" (2014, p. 69). 
Há, entre a erupção de um vulcão e uma erupção de raiva, um vasto gradiente de contextos agônicos facilmente sobreponíveis às qualidades de uma obra, a ponto de a esmagar. Parece mais fácil conceber a destruição trágica de uma obra-prima do que a cômica intemporalidade de uma obrada. Ilógica parece a longevidade de uma obra que não manifeste certas esmagadoras qualidades, entre as quais me atrevo a destacar a exigência. Será possível que a obra permaneça porque tem condições de exigir a própria releitura? Teria Brás esmagado a borboleta se não fosse preta e sim azul (ASSIS, 2013, p. 100)? A cor é a qualidade decisiva; e o azul exige, ao contrário do preto, a contemplação da borboleta no expoente do seu dinamismo, ou seja, viva?

Machado de Assis é um autor defunto ou um defunto autor? Inclinome, sem dúvida, para a segunda hipótese. Embora não tenha escrito livros depois de morto, Machado enquanto autor nunca esteve morto. A longevidade do autor e da pessoa são coisas necessariamente diferentes. Não podemos chamar-lhe autor defunto hoje, senão injustamente; e nem quando estava vivo, pois era mais bem-sucedido que a maioria dos autores. Brás Cubas, ao contrário, foi um autor defunto até morrer.

Durante a viagem marítima para Portugal, o jovem torna-se íntimo do comandante, que com ele partilha poemas e conversas literárias e à chegada lhe prediz "um grande futuro" (ASSIS, 2013, p. 73). Anos depois, "meio recluso" na sequência da morte do pai e dos desentendimentos familiares conseguintes à partilha da herança, Brás descreve a sua atividade: "Escrevia política e fazia literatura. Mandava artigos e versos para as folhas públicas, e cheguei a alcançar certa reputação de polemista e de poeta” (ASSIS, 2013, p. 127). Quando vem a amar a casada Virgília, sente ciúmes e perde o sono, atirase "a ler e escrever" (ASSIS, 2013, p. 159). Quando finalmente se torna deputado, aos cinquenta anos, tem urgência de se apoderar da tribuna, lugar onde também havia imaginado o filho que não nasceu (ASSIS, 2013, p. 207). Escolhe o momento em que se discutia "o orçamento da Justiça” (ASSIS, 2013, p. 278) para introduzir e desenvolver com peculiar retórica o assunto da diminuição da barretina da Guarda Nacional. Poderia ter sido aplaudido numa reunião literária, mas não numa assembleia política que destinava fundos à justiça. Literatura e formalidade política andavam de mãos dadas desde a infância de Brás Cubas, que até morrer nunca se havia libertado da mão de uma para dar as duas mãos à outra.

A história inventada pelo pai acerca da origem do nome de família foi sendo sucessivamente reeditada pelo filho e transformou-se num cenário em 
que a única coisa concreta é a solução final, aquela em que o nome próprio não é soluto, mas solvente. Ou seja, aquela em que o nome próprio dilui o apelido da família em vez de se diluir nele. É isto que vai dançando na ponta do chocalho agitado pelo mágico. É esta a verdadeira e essencial sobremesa de Brás Cubas, a qual, por impaciência, nunca chega a provar em vida. Por apenas conceber o resultado, o meio de lá chegar fica pelo caminho. Quando se isola, escreve; mas nunca se isola para escrever.

O desaire do discurso da barretina provoca-lhe um desânimo que Quincas Borba, amigo íntimo, tenta contrariar. Diagnostica em Brás não a ambição verdadeira do poder, "mas um capricho, um desejo de folgar" (ASSIS, 2013, p. 283); como remédio sugere-lhe a fundação de um jornal que veio a tornar-se "aplicação política do Humanitismo", doutrina com que o programa anunciava vir a "derribar o atual ministério" (ASSIS, 2013, p. 292).

O primeiro número do meu jornal encheu-me a alma de uma vasta aurora, coroou-me de verduras, restituiu-me a lepidez da mocidade. Seis meses depois batia a hora da velhice, e daí a duas semanas, a da morte, que foi clandestina, como a de D. Plácida. (ASSIS, 2013, p. 300)

Brás deixa de fazer literatura na assembleia política e tenta fazer política num jornal literário a ponto de advogar que derribará o poder com uma doutrina baseada em livro inédito! Se o efeito benéfico não foi suficiente para acalentar no autor o entusiasmo do processo, o que dizer da clandestinidade precoce do jornal? A falta de arruído leva-o a desistir da ideia até que outra se fosse pendurar no trapézio. Assim se comprova que Brás Cubas era um autor defunto, antes de se tornar um defunto autor. A teoria é suportada pelas diversas metáforas de compositor, como a da pena que vai "comendo papel”, a dos formatos tipográficos (ASSIS, 2013, p. 80), a "teoria das edições humanas" (ASSIS, 2013, p. 29, 110) e a "errata pensante" (ASSIS, 2013, p. 92): tropos que remetem a memórias prévias relativas ao universo da escrita e da publicação.

\section{A última edição}

A morte é, assim, um início para Brás Cubas, "outro berço" transfigurador que lhe dá a possibilidade de ser "defunto autor" (ASSIS, 2013, p. 19). É também o berço do romance, uma vez que o estatuto póstumo é declarado não apenas no título, como no prólogo: “[...] evito contar o processo extraordinário que empreguei na composição destas Memórias, trabalhadas 
cá no outro mundo. Seria curioso, mas nimiamente extenso, e aliás desnecessário ao entendimento da obra. A obra em si mesma é tudo [...]" (ASSIS, 2013, p. 17). Comentário paralíptico, informa-nos acerca de algo que declara não dizer. É óbvio que o processo é curioso e extraordinário: havia necessidade de frisá-lo? Sim. O mais importante não é saber como aconteceu, mas saber que aconteceu o processo do qual a obra em si mesma é fruto extraordinário. $\mathrm{O}$ autor retoma a morte no último capítulo. Faz um balanço da vida e conclui que se acha, do "outro lado do mistério", com um "pequeno saldo, que é a derradeira negativa deste capítulo de negativas" (ASSIS, 2013, p. 314). Como refere Baptista, "a analogia contabilística não exclui nem mascara o processo de deitar contas, de dar contas - de prestar contas da vida vivida, com o duplo sentido de a tornar inteligível e de responder por ela.” (2014, p. 31).

O defunto autor não se ocupa da descrição do "undiscovered country de Hamlet" senão através de perífrases. Expressões como "eternidade do nada" (ASSIS, 2013, p. 29), "o grande mergulho nas trevas" (ASSIS, 2013, p. 53), "cova que nunca mais se abre" (ASSIS, 2013, p. 72), "Abismo do Inexplicável” (ASSIS, 2013, p. 83) etc., permitem-nos inferir que a morte é como um buraco negro. Mas a posição do autor também nos permite inferir certas condições metafísicas implícitas.

A primeira, óbvia, é que a consciência pode existir depois da morte, confinada a uma espécie de treva sem fim aparente. A segunda, explícita no final, aponta para a existência de um sistema de regulação universal à semelhança da balança de Maat, deusa egípcia da justiça e da verdade, em que a alma responde pela vida após a morte.

Assim, o romance exige do leitor o que a morte exige à consciência. Imaginemos um cenário em que a morte e a justiça podem ser um pouco trapaceiras. A consciência pousa na balança, pesam-na, entreolham-se cumplicemente e exigem-lhe uma revisão da vida vivida. Apetrechada de novas subtilezas, a consciência recorda-se de tudo com maior clareza. Se é das mais inadvertidas, não imagina que a proposta possa ser uma rasteira filosófica e, além disso, decisiva ao progresso da alma. No fundo, um enigma como o da Esfinge. Começa a ditar a autobiografia, do nascimento até à morte, enumeração de eventos, sucessos e insucessos. A morte e a justiça deixam-na terminar, como é suposto. No fim, renovam a exigência de revisão da vida vivida, e assim sucessivamente... Com uma consciência avisada passa-se o oposto: pressente ali um mistério e uma partida. Contempla a vida vivida e sabe que a revisão não pode ser simplesmente enumerativa. Sabe ainda que 
poderia ofender as porteiras chegando à conclusão de que a vida não faz sentido, e é melhor não o fazer. Eis que está quase a desesperar... e eureca! É óbvio que as memórias prévias e as memórias póstumas não podem nem devem coincidir! E, para garantir sem falibilidade as graças das sentinelas, o melhor é entretê-las com uma espécie de romance. Quem sabe até não gostam e o mandam publicar... defunto autor etc.

A terceira, já referida, é a duplicidade do canal de transmissão entre o mundo da vida e o "outro mundo" (ASSIS, 2013, p. 17). O livro prova que a informação pode regressar.

\section{0 despropósito}

No capítulo de parábase "O Bibliômano" (ASSIS, 2013, p. 173), o autor declara ter escrito, nas últimas linhas do capítulo anterior, "uma frase muito parecida com despropósito". E imagina que um "bibliômano”, afeiçoado ao que descobre ser um "exemplar único", não consegue descobri-lo. Em primeiro lugar, verificamos o contraste entre as fantasias de Brás Cubas e do defunto autor: o primeiro via o nome impresso por todo o lado, o segundo imagina um leitor que amaria o seu livro precisamente por se tratar de um exemplar único: "[...] faria a mesma cousa com o Almanaque de Laemmert, uma vez que fosse único" (ASSIS, 2013, p. 173).

Em segundo lugar, a óbvia ironia caricatura aqueles que amam os livros pela raridade numérica dos exemplares, em detrimento da raridade da obra, enquanto objeto propriamente literário. Podemos deduzir que esse "bibliômano" não encontra o "despropósito" por mais que leia, releia, tresleia etc., porque é cego relativamente à originalidade ou invulgaridade no sentido qualitativo do termo. Que despropósito é esse que o "bibliômano" não conseguia ver?

"O senão do livro" (ASSIS, 2013, p. 172), capítulo cujas "últimas linhas" contêm o despropósito, é também de parábase. O autor declara que o "vício grave" do livro - trazer "certa condição cadavérica" - é "ínfimo" quando comparado com o seu "maior defeito": o leitor. A justificação de Brás Cubas é paradoxal. A condição do morto, segundo ele, é a condição de quem tem tempo presente - “[...] expedir alguns magros capítulos para esse mundo sempre é tarefa que distrai um pouco da eternidade [...]" (ASSIS, 2013, p. 172) - e manifesta-se estilisticamente “como os ébrios”. O leitor, sóbrio, prefere uma "narração direta e nutrida" e rejeita o estilo não linear da condição cadavérica: a condição do vivo é não ter tempo, dado que abdica do presente em prol de um desenvolvimento futuro - "tem pressa de envelhecer". Adiante, porém, em 
outro capítulo de parábase intitulado "Vá de intermédio" (ASSIS, 2013, p. 262), o autor atribui "uma dose de verdade" a um pensamento que afirma não lhe pertencer: ninguém lê "senão para escapar à vida". Pisará a ficção o território da morte? Não deixa de ser despropositado termos vindo parar a este capítulo sabendo que há um “despropósito” à solta nas últimas linhas do outro:

E caem! - Folhas misérrimas do meu cipreste, heis de cair, como quaisquer outras belas e vistosas; e, se eu tivesse olhos, dar-vos-ia uma lágrima de saudade. Esta é a grande vantagem da morte, que, se não deixa boca para rir, também não deixa olhos para chorar... Heis de cair. (ASSIS, 2013, p. 172)

As folhas do cipreste de Brás Cubas caem como os ébrios. Quem as faz cair assim é a pena do defunto autor. $\mathrm{O}$ cipreste representa as memórias que vai escrevendo e está a ficar sem folhas, ou seja, o autor está prestes a completar a revisão. Não fica indiferente; o "desdém dos finados" (ASSIS, 2013, p. 84) não diz respeito à atividade de rememoração em si, mas à ausência de filtros moralistas no desfiar das memórias. O curioso é que apesar de as folhas misérrimas caírem como as belas, a lágrima de saudade, se tivesse olhos, seria dada às primeiras, não às segundas.

Serias antes da opinião, gentil legente, de que o despropósito tem a ver com o reforço da ausência do corpo? Tornar evidente a ausência de uma mão a segurar a pena que faz cair as folhas é ou não é um tiro num pé inexistente? Discordo. Recorda-te da parte 1 deste artigo, em que falei sobre a curiosidade: precisamente o que o “despropósito" vem aguçar.

Brás Cubas termina o parágrafo dando ênfase à fatalidade da queda. Eventualmente, cairão todas as folhas do seu cipreste, e depois? Acabam-se, publica-se o livro? Espero que não consideres essas perguntas despropositadas.

\section{0 delírio}

Os delírios tendem a ser desprezados. Se achas que é um delírio afirmar que Brás Cubas é precursor de Einstein e de Stephen Hawking, o melhor é saltares este item. Brás Cubas escolhe relatá-lo porque "é interessante" e, sendo a primeira vez que alguém o faz, a ciência lho "agradecerá". O capítulo VII é dos mais longos do livro e trata de uma modalidade de revelação, semelhante à máquina do mundo, mas a sua seriedade é habitualmente 
rebatida. O vexame infantil do humano face à vertigem da mãe Natureza não ajuda a que seja levado em conta; muito menos, a conotação negativa do delírio, que impera no nosso mundo definido pelos valores da razão, ou seja, justo e pacífico.

A verdade é que no tempo de Cícero ou de Camões as revelações seguiam rígidas formalidades. O sonho de Cipião e a visão da máquina do mundo refletiam conhecimentos empíricos e especulativos difundidos no respetivo presente histórico. Além de o delírio de Brás Cubas ser um hino à liberdade espiritual, o mais surpreendente é que incorpore teorias científicas que viriam a revolucionar a forma como olhamos o universo. Delirante!

A sandice, que a razão expulsa da consciência no capítulo seguinte, confessa andar na pista de dois mistérios, "o da vida e o da morte" (ASSIS, 2013, p. 39). Sabemos hoje que o palco dessa exploração é o tecido espaçotemporal: “[...] nós vamos à origem dos séculos”, responde o hipopótamo (literalmente, cavalo do rio) que serve de veículo a Brás Cubas (ASSIS, 2013, p. 32).

Ao contrário dos grandes heróis, nosso protagonista sentia-se temeroso e aturdido com a frieza alva e imensa do silencioso nada. Surge então a "Natureza ou Pandora", "mãe e inimiga"; tudo na figura contraditória "escapava à compreensão do olhar humano" (ASSIS, 2013, p. 34). Declara que a sua inimizade se afirma pelo flagelo da vida, ou seja, pela "miséria" cujo "legado" o autor declara não ter transmitido, na "derradeira negativa" do romance, "a nenhuma criatura" (ASSIS, 2013, p. 314). Sendo não "somente a vida", mas "também a morte”, Brás implora-lhe pela vida, mas a resposta foi que a dele deixara de ser necessária (ASSIS, 2013, p. 35).

Só "o tempo subsiste" (ASSIS, 2013, p. 36): levado ao topo da montanha, o futuro morto vê os séculos desfilarem; dentro deles, o humano, joguete da fatalidade. Rindo, suplica à Natureza: "abre o ventre, e digere-me" (ASSIS, 2013, p. 37). Conformado, comprova a "regularidade de calendário" da vida humana e lá anseia pelo final do tempo, na expectativa de que a visão do último século lhe dê "a decifração da eternidade" (ASSIS, 2013, p. 37). Mas, nesse ponto, "já a rapidez da marcha era tal, que escapava a toda a compreensão; ao pé dela o relâmpago seria um século" (ASSIS, 2013, p. 38).

Imagino que Einstein tenha lido esse capítulo antes de formular a teoria da relatividade especial em 1905, pondo em causa as leis de Newton e a noção de tempo, que até então se julgava constante e imutável. O facto de a velocidade da luz ser invariável, ao contrário da maioria das coisas no 
universo, levou o gênio à flor de um delírio imaginativo que constituiu uma revolução gnosiológica.

Um indivíduo está na plataforma da estação de comboios, segurando um relógio bem diferente daqueles que Quincas Borba roubou e restituiu a Brás Cubas. Este é feito de luz e ótica: um fotão balança verticalmente entre dois espelhos. Outro indivíduo viaja de comboio com relógio idêntico. A locomoção do comboio imprime ao fotão um movimento horizontal, pelo que lá dentro cada oscilação vertical parece durar mais tempo. Se o tempo passa mais devagar num comboio a andar, mais espaço pode ser percorrido em menos tempo. O tempo depende do movimento; e, a certa altura, de forma dramática. Se a velocidade do comboio atingisse $99 \%$ da velocidade da luz, um dia no comboio equivaleria a uma semana na plataforma, ao passo que a 99,999999999999999\% da velocidade da luz, um dia no comboio equivaleria, na plataforma, a vinte mil anos. Décimas, centésimas, milésimas etc.: são como asas de borboleta. A dilação do tempo experimentada por Brás Cubas no delírio é como o comboio de Einstein. Hoje, a ciência tenta replicá-la através de máquinas como o LHC, o maior acelerador de partículas do mundo.

Mas, como dizia, todo o livro é delirante. Salto a teoria da relatividade geral (1915) e passo aos buracos negros que a ela tanto devem, descritos pela primeira vez em 1916. Se bem te lembras, referi anteriormente que o autor descreve a morte como um desses buracos. São epítomes do desconhecido: resultam do colapso das grandes estrelas e sugam tudo em derredor; lá dentro são as leis da física que colapsam, o tempo para e o espaço é infinito. Cada uma dessas fissuras no tecido do universo é rodeada por uma barreira chamada horizonte de eventos. Ironia do destino, o objeto mais invisível do universo torna-se o mais luminoso, quando devora uma estrela. Passada a barreira do horizonte de eventos, nada pode retornar...

Ou assim se pensava, até que Hawking escreveu as Memórias póstumas dos buracos negros, ${ }^{1}$ certamente depois de ler as de Brás Cubas. Estou a brincar, mas não muito: os buracos negros irradiam partículas, portanto vão evaporando lentamente, até a morte. Lembras-te das folhas do cipreste? As Memórias póstumas correspondem à edição final de Brás Cubas, última errata impressa em retalho separado do original. Porém, além de corrigirem, substituem o original e tornam-se mais importantes do que ele. Só depois de

\footnotetext{
${ }^{1}$ Hawking descreve a radiação emitida pelos buracos negros no capítulo "Black Holes Ain’t So Black”, do livro A Brief History of Time - publicado pela editora Bantam em 1988. Em 1991, Errol Morris dirigiu um documentário sobre Hawking, com o mesmo título, em que Hawking descreve assim o fenómeno: "If black holes have an entropy, they ought to have a temperature. And if they have a temperature, they ought to give off radiation... I found that particles could escape from a black hole. That black holes are not completely black."
} 
morrer é que o autor emprega com sucesso a "distinção psíquica" que a vida lhe dera para inventar uma maneira de escapar à morte.

A força da errata é como a da natureza. Contribui para a forma livre dos capítulos, em si pequenas erratas. É a flor do nascimento, que eventualmente terá fim. E a flor, grande motivo metafórico do romance - e recorrente em Machado de Assis -, é a revelação da natureza movida por uma inteligência superior, ato dinâmico representativo do "desejo de folgar", inacabado perfeito, volúpia da imaginação como a escrita e a leitura podem ser.

$\mathrm{E}$ tu, gentil legente, não esqueças nunca a prova de que a imaginação nos pode levar a irradiar de qualquer buraco metido em trevas.

\section{Referências}

ASSIS, Machado de. Memórias póstumas de Brás Cubas: curso breve de literatura brasileira. v. 1. Lisboa: Livros Cotovia, 2013.

BAPTISTA, Abel Barros. A Vênus manca (emenda de Pascal). In: Três emendas: ensaios machadianos de propósito cosmopolita. São Paulo: Editora da Unicamp, 2014. p. 31-94.

EINSTEIN AND HAWKING: Unlocking the Universe. Documentário. Diretor: Michael Lachmann. BBC, Reino Unido, 2019. 1h 22 min.

LORENZ, Edward. Predictability; Does the Flap of a Butterfly's wings in Brazil Set Off a Tornado in Texas?. Cambridge, 1972. Disponível em: $<$ http://eaps4.mit.edu/research/Lorenz/Butterfly_1972.pdf>. Acesso em: 4 abr. 2020.

DIANA DUARTE FERREIRA é aluna de Doutoramento em Estudos Portugueses na Faculdade de Ciências Sociais e Humanas da Universidade Nova de Lisboa. Destaca literatura brasileira, teoria da literatura e estudos interartes como áreas de interesse e pesquisa académica. Instrumentista e criadora do Projecto Poeta, explora convergências entre música e poesia, autoria e apropriação.

(iD) https://orcid.org/0000-0002-7554-2715. E-mail: diana.duart@icloud.com

Recebido: 16.04.2020

Aprovado: 10.09.2020 